\title{
Characteristics and origin of peperite involving coarse-grained host sediment
}

\author{
Richard J. Squire, Jocelyn McPhie* \\ Centre for Ore Deposit Research and School of Earth Sciences, University of Tasmania, Hobart, TAS 7001, Australia
}

Received 20 February 2000; accepted 25 August 2000

\begin{abstract}
Peperite involving basalt and polymictic volcanic conglomerate occurs in the Pliocene Ba Volcanic Group at Yaqara in northern Viti Levu, Fiji. Because the host sediment is coarse-grained and dominated by basalt clasts, the peperite could be easily overlooked and mistaken for another coarse volcaniclastic facies. However, the presence of groups of basalt clasts that show jigsaw-fit texture, fluidally shaped basalt clasts with complete glassy margins, gradational contacts with adjacent sedimentary facies and the absence of stratification indicate that molten basalt mingled with unconsolidated gravel. Using these criteria, we show that other superficially similar, coarse, polymictic facies with fluidal basalt clasts are not peperite. Both blocky and fluidal basalt clasts occur together in the peperite. The amoeboid basalt clasts in the fluidal peperite result from dismembering of ductile, low-viscosity, relatively hot magma. At this stage, propagating magma lobes were probably insulated from direct contact with the wet sediment by a vapour film. The angular, polyhedral basalt clasts in the blocky peperite indicate brittle disintegration of somewhat cooler, higher-viscosity magma. The presence of jigsaw-fit texture and polyhedral clasts with glassy margins suggest that quench fragmentation of the basalt was important in the formation of the blocky peperite. Although there is no positive evidence for steam explosivity, the presence of steam could be recorded by small quartz-filled cavities that occur within the host sediment. The co-existence of fluidal and blocky basalt clasts is interpreted to reflect successive ductile then brittle fragmentation of intruding magma. The change from fluidal to blocky peperite might have resulted from progressive cooling of the magma during intrusion, and also from the breakdown of fluidisation when the limited supply of fine sediment in the host gravel was exhausted. (c) 2002 Elsevier Science B.V. All rights reserved.
\end{abstract}

Keywords: basalt-gravel peperite; basaltic sill; polymictic volcanic conglomerate; submarine volcanic succession; Fiji; Pliocene

\section{Introduction}

The active volcanic settings in which peperite is formed are typically depocentres for diverse sedimentary facies that can include large volumes of

\footnotetext{
* Corresponding author. Tel.: +61-3-6226-2476; Fax: +61-3-6226-7662.

E-mail address: j.mcphie@utas.edu.au (J. McPhie).
}

coarse volcanic breccia and volcanic conglomerate. However, most peperite described in the literature involves relatively fine-grained sediment (Brooks et al., 1982; White and Busby-Spera, 1987; Hanson, 1991; Hanson and Wilson, 1991, 1993; Boulter, 1993; Rawlings, 1993; Mueller et al., 1994; Brooks, 1995; Goto and McPhie, 1996; Hanson and Hargrove, 1999). There are few descriptions involving coarse-grained host sediment (Busby-Spera and White, 1987; Hanson and Wil- 
son, 1991), perhaps because of difficulties in identification rather than low abundance. The difficulties arise because clasts derived from the magma may be similar in texture, size and shape to igneous clasts in a volcaniclastic host. This is especially true in cases involving blocky peperite and volcanic breccia. Host sediment properties (grain size, porosity, permeability) may influence intrusion and fragmentation processes during peperite formation (e.g. Kokelaar, 1982, 1986; BusbySpera and White, 1987). Cases involving coarse host sediment can thus be expected to illustrate relationships not evident in the more commonly described cases involving fine-grained sediment. Therefore, detailed description and interpretation of peperite involving coarse host sediment are important in achieving a better understanding of peperite formation, and in developing criteria for peperite identification.

In this paper we describe and interpret examples of peperite in coarse submarine volcaniclastic facies of the Pliocene Ba Volcanic Group, northern Viti Levu, Fiji. Both blocky and fluidal peperite have developed as a result of the interaction of basaltic magma with coarse volcanic conglomerate and breccia. Because the magma composition and the character of the host sediment are the same in these examples, it is apparent that other factors have influenced magma fragmentation and mingling processes.

\section{Geological setting}

Peperite occurs in excellent exposures at three localities along Naidadara Creek and one of its major tributaries about $15 \mathrm{~km}$ east of Tavua on the main island of Viti Levu, Fiji (Fig. 1). All three sites are within the Yaqara Pastoral Station. The basaltic volcanic succession in this area is part of the Ba Volcanic Group, the age of which ranges from 5.5 to $3.0 \mathrm{Ma}$ (Colley and Greenbaum, 1980; Rodda and Kroenke, 1984; Whelan et al., 1985; Gill, 1987). The group is partly coeval with the Pliocene andesitic rocks of the Koroimavua Volcanic Group in the west (Rodda, 1967; Dickinson, 1968; Colley and Hindle, 1984) and overlies Miocene or older sedimentary

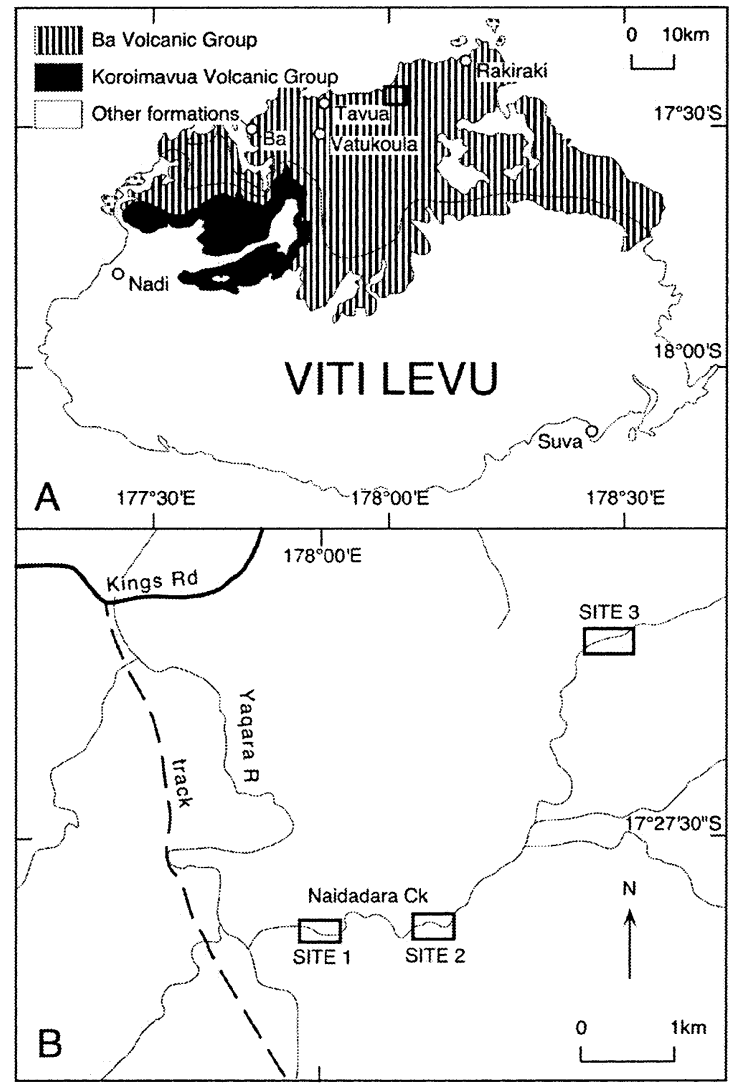

Fig. 1. (A) Simplified geological map of Viti Levu showing the distribution of the Pliocene Ba and Koroimavua Volcanic Groups (modified after Rodda, 1967). The Yaqara region (outlined) is shown in more detail in (B). (B) Location of detailed volcanic facies mapping sites 1,2 and 3 (refer to Figs. 3-5, respectively) showing major creeks, roads and tracks.

formations elsewhere (Rodda, 1967; Colley and Flint, 1995). The total thickness of the Ba Volcanic Group is interpreted to be between 1500 and $3000 \mathrm{~m}$ (Colley and Flint, 1995).

The Ba Volcanic Group comprises gently dipping basaltic lavas, including pillow lava, and texturally diverse volcanic breccia interbedded with volcanic conglomerate and sandstone (McPhie, 1995). McPhie (1995) recognised three main facies associations in the Ba Volcanic Group at Rakiraki in northeastern Viti Levu: (1) primary volcanic facies (lavas, autoclastic breccia, peperite); (2) resedimented volcaniclastic facies (pillow-fragment breccia, resedimented hyaloclastite, resedi- 
mented lapilli breccia); and (3) volcanogenic sedimentary facies (volcanic conglomerate, sandstone turbidites, suspension-settled mudstone). The facies associations were interpreted to represent a shoaling basaltic seamount and most were deposited in a submarine setting, below wave base (McPhie, 1995). Subvertical mafic dykes are also abundant in the Ba Volcanic Group (Rodda, 1976; Seeley and Searle, 1970).

\subsection{The Ba Volcanic Group at Yaqara}

Broadly similar facies to those at Rakiraki are present in the Ba Volcanic Group at Yaqara. Coarse volcanic conglomerate and volcanic breccia interbedded with volcanic sandstone predominate over basaltic pillow lava and massive basaltic units. As at Rakiraki, the presence of pillow lava and hyaloclastite at Yaqara implies a submarine depositional setting. The occurrence of massive to graded bedforms, and the absence of wave-generated sedimentary structures, such as symmetrical ripples or bi-directional palaeocur-

Table 1

XRF major element chemical analyses of the sparsely porphyritic (samples 1 and 2) and highly porphyritic (samples 3 and 4) basalts in the Ba Volcanic Group at Yaqara ${ }^{\mathrm{a}}$

\begin{tabular}{lcccc}
\hline & $\begin{array}{l}\text { Sample 1 } \\
(143586)\end{array}$ & $\begin{array}{l}\text { Sample 2 } \\
(143597)\end{array}$ & $\begin{array}{l}\text { Sample 3 } \\
(143608)\end{array}$ & $\begin{array}{l}\text { Sample 4 } \\
(143590)\end{array}$ \\
\hline $\mathrm{SiO}_{2}$ & 52.61 & 54.46 & 48.75 & 49.33 \\
$\mathrm{TiO}_{2}$ & 0.65 & 0.59 & 0.74 & 0.80 \\
$\mathrm{Al}_{2} \mathrm{O}_{3}$ & 18.51 & 17.29 & 15.53 & 18.27 \\
$\mathrm{Fe}_{2} \mathrm{O}_{3}$ & 9.15 & 7.48 & 10.04 & 9.87 \\
$\mathrm{MnO}$ & 0.15 & 0.15 & 0.17 & 0.17 \\
$\mathrm{MgO}$ & 3.78 & 6.44 & 9.41 & 6.11 \\
$\mathrm{CaO}$ & 8.43 & 5.14 & 11.45 & 11.44 \\
$\mathrm{Na}_{2} \mathrm{O}$ & 3.54 & 3.27 & 1.81 & 2.49 \\
$\mathrm{~K}_{2} \mathrm{O}$ & 2.48 & 4.62 & 1.77 & 1.26 \\
$\mathrm{P}_{2} \mathrm{O}_{5}$ & 0.72 & 0.56 & 0.33 & 0.27 \\
L.O.I. & 4.49 & 3.37 & 0.80 & 2.47 \\
\hline
\end{tabular}

a Sample locations: sample 1 from facies $1,177^{\circ} 59^{\prime} 57^{\prime \prime} \mathrm{E}$, $17^{\circ} 28^{\prime} 05^{\prime \prime} \mathrm{S}$ (site 1, Fig. 3); sample 2, from facies 3, $178^{\circ} 00^{\prime} 41^{\prime \prime} \mathrm{E}, 17^{\circ} 28^{\prime} 03^{\prime \prime} \mathrm{S}$ (site 2, Fig. 4); sample 3, from pillow basalt, $178^{\circ} 01^{\prime} 41^{\prime \prime} \mathrm{E}, 17^{\circ} 26^{\prime} 21^{\prime \prime} \mathrm{S}$ (site 3, Fig. 5); sample 4, from columnar-jointed massive basalt, ca. $800 \mathrm{~m}$ southwest of sample $3,178^{\circ} 01^{\prime} 27^{\prime \prime} \mathrm{E}, 17^{\circ} 26^{\prime} 37^{\prime \prime} \mathrm{S}$. University of Tasmania catalogue numbers are given below the sample numbers. All analyses have been recalculated to $100 \%$ volatile free. rent indicators, suggest that the setting was below wave base. Bedding dips very gently to the northeast at sites 1 and 2 and gently to the west at site 3 in the north.

Two basalt types occur in the $\mathrm{Ba}$ Volcanic Group at Yaqara: sparsely plagioclase-, clinopyroxene-, ( \pm olivine)-phyric basalt (samples 1 and 2 ) and highly clinopyroxene-, plagioclase-, olivinephyric basalt (samples 3 and 4) (Table 1). The sparsely porphyritic basalt contains slightly higher $\mathrm{SiO}_{2}, \mathrm{Na}_{2} \mathrm{O}, \mathrm{P}_{2} \mathrm{O}_{5}$ and $\mathrm{K}_{2} \mathrm{O}$, slightly lower $\mathrm{TiO}_{2}$ and $\mathrm{MgO}$, and significantly lower $\mathrm{CaO}$ than the highly porphyritic basalt. Both have high $\mathrm{K}_{2} \mathrm{O}$ contents. The sparsely porphyritic basalt is shoshonitic, whereas the highly porphyritic basalt straddles the boundary between shoshonites and the high-K calc-alkaline series, as defined by Le Maitre et al. (1989) and Rickwood (1989). The two textural types are easily distinguished in the field by the presence or absence of abundant, coarse clinopyroxene and olivine phenocrysts.

The coarse clastic facies at Yaqara include four types of polymictic volcanic breccia and a polymictic volcanic conglomerate interbedded with volcanic sandstone. We use 'polymictic volcanic breccia' in a descriptive sense to imply clast types, shapes and size. On the basis of facies relationships and texture, we interpret some of the polymictic volcanic breccia facies to be peperite in which the host sediment is volcanic conglomerate or breccia.

Volcanic sandstone is present as laminated to thinly bedded intervals up to $3 \mathrm{~m}$ thick; beds are tabular and graded bedding is common. The principal components are volcanic lithic and crystal (augite and feldspar) fragments. The polymictic volcanic conglomerate (Fig. 2) occurs in medium to very thick, internally massive to diffusely planar layered or weakly graded beds. It is composed of well-rounded pebbles and cobbles of basalt $(>50 \%)$ in a matrix that in some places is dominated by coarse volcanic sand and in others by a mixture of sand and angular granules and fine pebbles of basalt. The pebbles and cobbles mainly consist of strongly vesicular and non-vesicular, coarsely clinopyroxene-phyric basalt.

Three of the polymictic volcanic breccia facies (facies 1, 2, 3) contain both sparsely and highly 


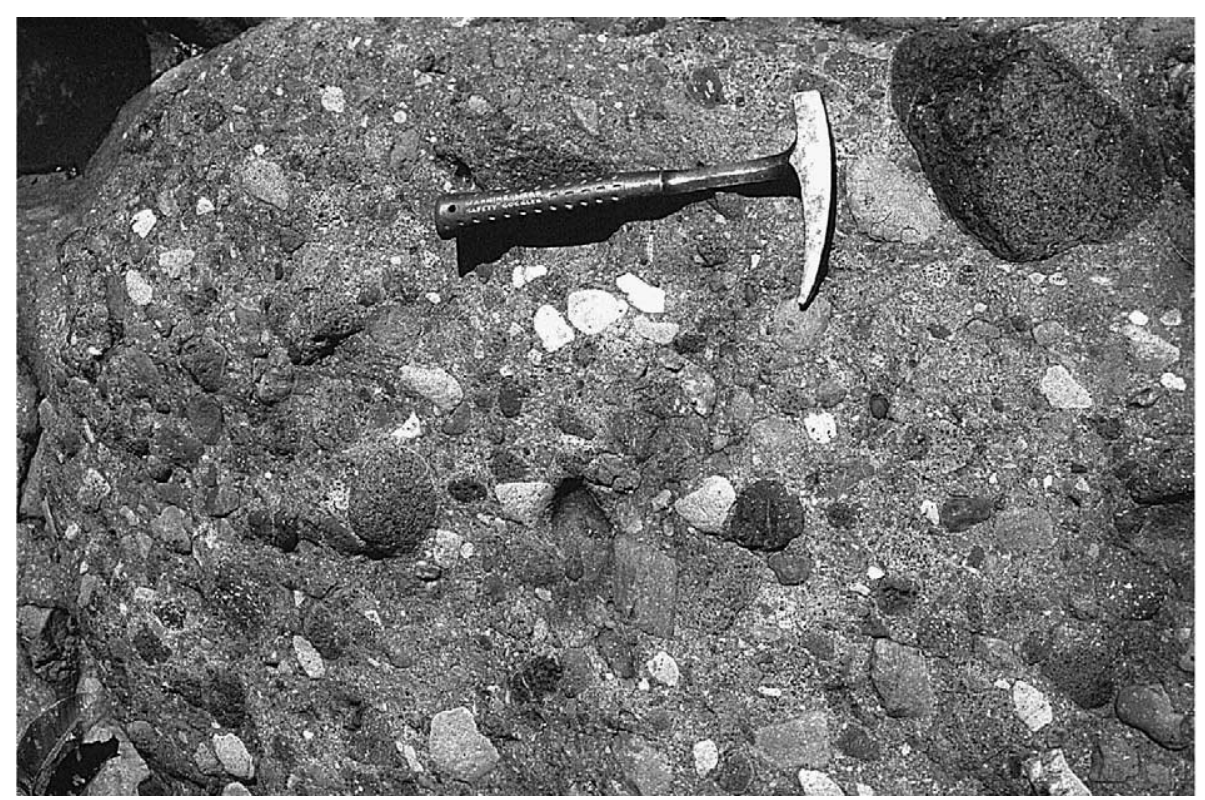

Fig. 2. Polymictic volcanic conglomerate at site 2, comprising well-rounded to subangular pebbles and cobbles in volcanic lithic sandstone matrix. The clasts are predominantly coarsely porphyritic basalt. Hammer is $32 \mathrm{~cm}$ long.

porphyritic basalt clasts and one facies (facies 4) contains only highly porphyritic basalt clasts. Data for the breccias with sparsely porphyritic basalt clasts were obtained from sites 1 and 2 along the Naidadara River (Figs. 3 and 4), whereas data for the breccia with highly porphyritic basalt clasts were obtained from site 3 (Fig. 5). In following sections, the different types of polymictic volcanic breccia facies and facies associations are described and interpreted.

\section{Polymictic volcanic breccia with sparsely porphyritic basalt clasts (facies $1,2,3$ )}

The three facies of polymictic volcanic breccia with sparsely porphyritic basalt clasts (Figs. 3 and 4) are non-stratified, poorly sorted and contain angular fragments of sparsely $(<5$ modal $\%$ ) plagioclase-, clinopyroxene- and olivine-phyric basalt.

Facies 1 contains greater than $90 \%$ angular, polyhedral, sparsely porphyritic basalt clasts. The presence of minor, well-rounded, coarsely pyroxene-phyric basalt clasts results in this facies being polymictic. The polyhedral, sparsely por- phyritic basalt clasts have well-developed glassy margins up to $4 \mathrm{~mm}$ thick and commonly occur in groups that show jigsaw-fit texture. The stratigraphic thickness of this facies is generally $<3 \mathrm{~m}$ but highly variable (Fig. 6). A few sparsely porphyritic basalt clasts are ovoid with internal concentric fractures (cf. 'concentric pillow breccia', Yamagishi, 1991). The well-rounded porphyritic basalt clasts vary from non-vesicular to highly vesicular and range in size up to $20 \mathrm{~cm}$. About $15 \%$ of these clasts are red or yellow-brown as a result of oxidation. Most of the rounded highly porphyritic clasts are widely dispersed among the angular, sparsely porphyritic basalt clasts. However, a few occur wholly within clasts of sparsely porphyritic basalt that show well-developed radial joints (Fig. 7). The rounded porphyritic clasts are identical in shape and texture to the dominant clast type in the adjacent polymictic volcanic conglomerate.

Facies 2 is the most common in the sections mapped and is distinguished from facies 1 by a lower proportion (generally $<60 \%$ ) of angular, polyhedral, sparsely porphyritic basalt clasts (Fig. 8). This facies is dominated by a mixture of rounded polymictic volcanic pebbles and cob- 


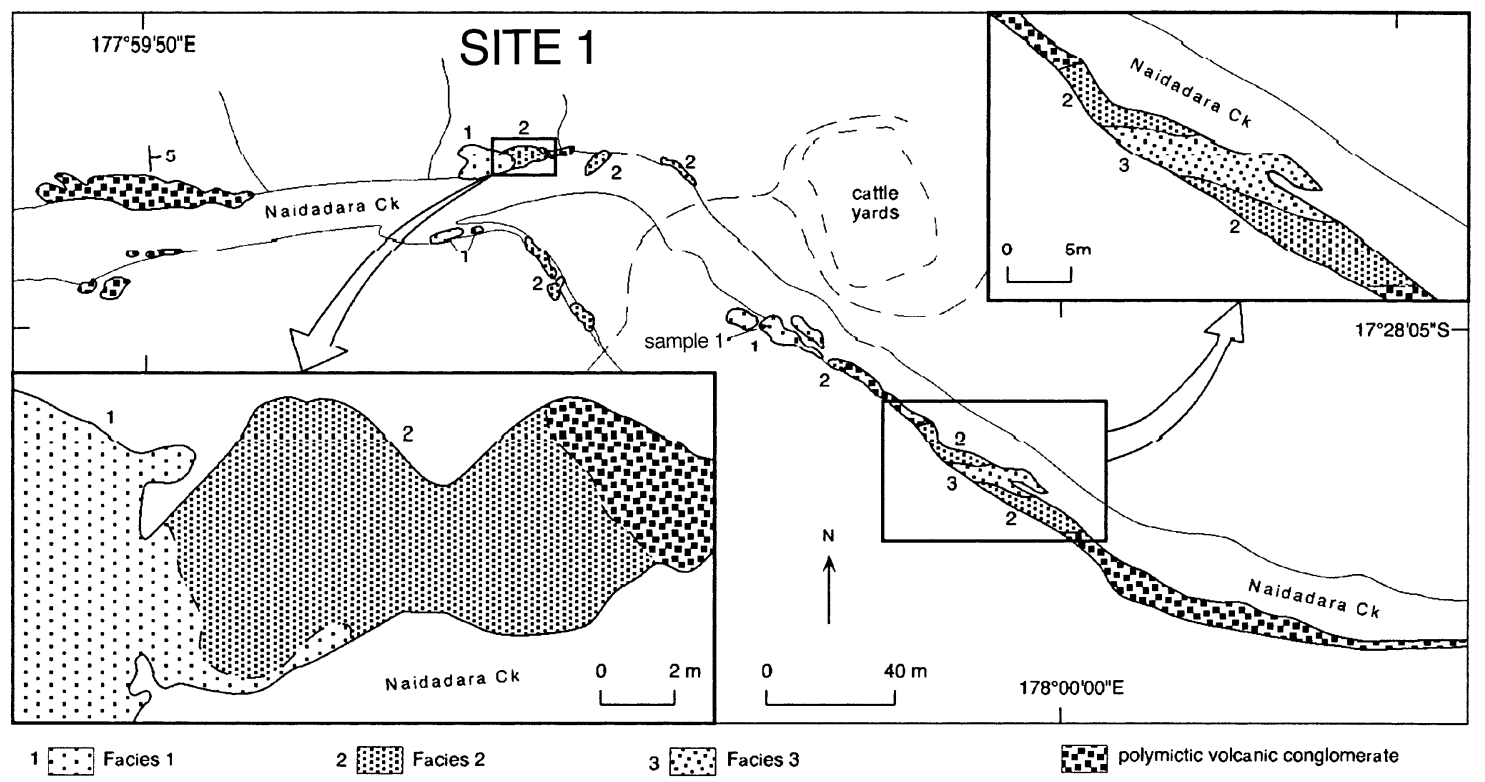

Fig. 3. Map of the volcanic facies along Naidadara Creek at site 1. The two outcrops shown in detail include polymictic breccia that has dominantly polyhedral (facies 2) or dominantly amoeboid (facies 3), sparsely porphyritic basalt clasts. Facies 1 is jigsawfit breccia composed of sparsely porphyritic basalt with scattered, round, coarsely porphyritic clasts.

bles in a matrix of volcanic sandstone and has a stratigraphic thickness up to $10 \mathrm{~m}$ (Fig. 6). The sparsely porphyritic basalt clasts have well-developed glassy margins up to $6 \mathrm{~mm}$ wide, especially in domains where they are very sparse. Where they are more common, groups of the sparsely porphyritic basalt clasts show jigsaw-fit texture (Fig. 8). Locally, cavities up to $4 \mathrm{~cm}$ across and partly filled with coarse quartz crystals (up to $1 \mathrm{~cm}$ ) occur in domains containing the largest (tens of $\mathrm{cm}$ across) sparsely porphyritic basalt clasts (Fig. 9). Also, in these domains the proportion of volcanic sandstone is lower than elsewhere.

Facies 3 is the least common but very distinctive in including fluidal or amoeboid, sparsely porphyritic basalt clasts up to $1 \mathrm{~m}$ long. The fluidally shaped clasts comprise at least $20 \%$ of the facies, have glassy margins up to $4 \mathrm{~mm}$ thick and well-developed internal fractures which in some cases are curviplanar (Fig. 10). The margins of the fluidal clasts are either smooth or highly irregular and crenulate on a fine scale. The stratigraphic thickness of the facies is generally $<3 \mathrm{~m}$ but highly variable (Fig. 6). Other components in this facies are similar to those in facies 2 and comprise angular, polyhedral sparsely porphyritic basalt clasts (up to $60 \%$ of the facies), rounded volcanic pebbles and cobbles (about 10\% of the facies) and volcanic sandstone (about $10 \%$ of the facies).

\subsection{Facies relationships and interpretation}

Contacts among the three facies of polymictic volcanic breccia with sparsely porphyritic basalt clasts are gradational, as are contacts with adjacent polymictic volcanic conglomerate. Transitions from one polymictic breccia facies to the other occur through stratigraphic thicknesses of $0.25-1 \mathrm{~m}$. Facies 1 appears to overlie polymictic volcanic conglomerate although the lower contact is not exposed. The upper contact of facies 1 is rapidly transitional into facies 2 , and facies 3 is always enclosed by facies 2 .

The shape and angularity of the polyhedral, sparsely porphyritic basalt clasts present in all three polymictic breccia facies suggest that they were originally formed by brittle fragmentation of sparsely porphyritic basalt. The presence of jig- 


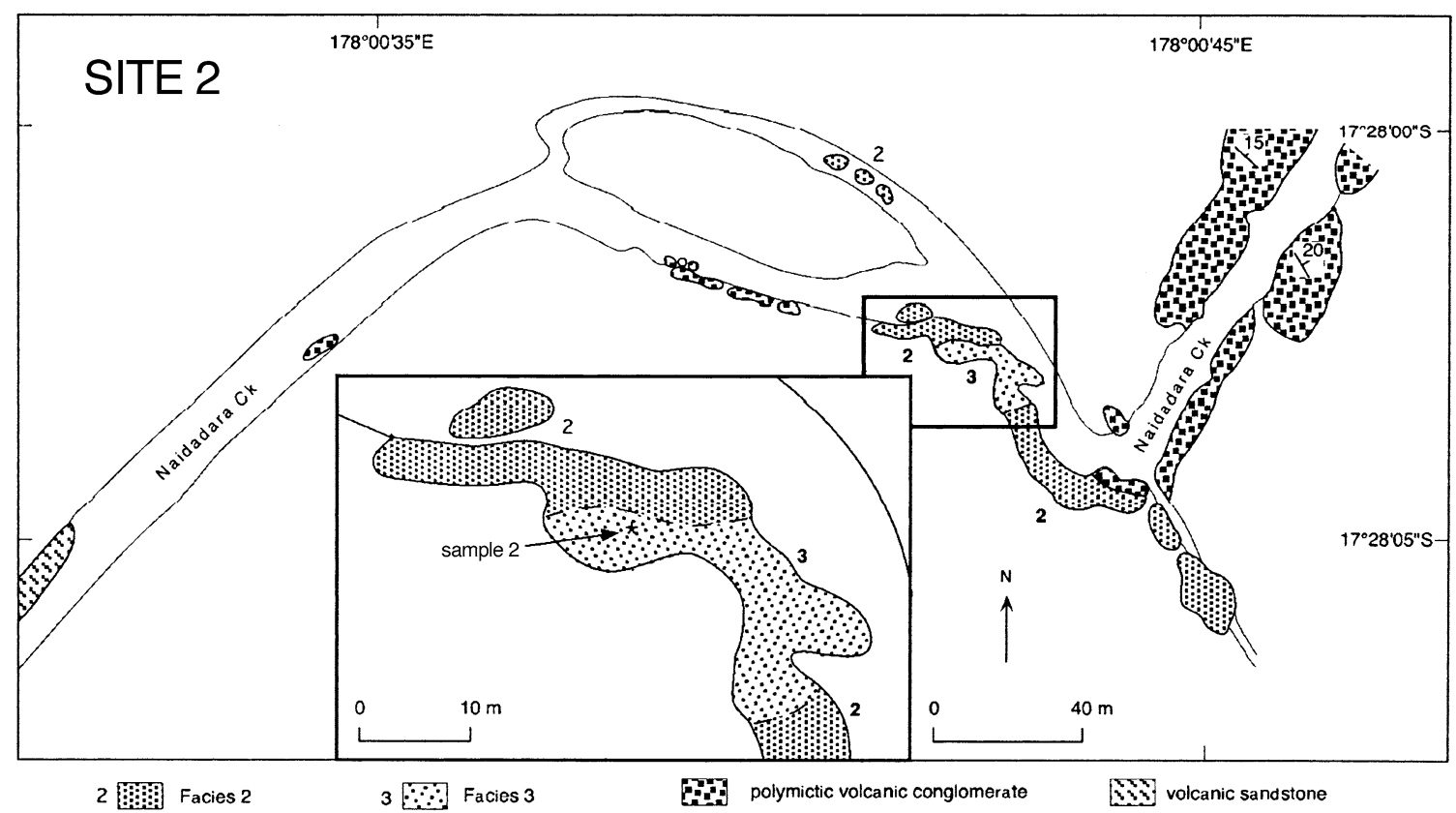

Fig. 4. Map of the volcanic facies along Naidadara Creek at site 2. The outcrop shown in detail comprises polymictic volcanic breccia in which the sparsely porphyritic basalt clasts are either amoeboid (facies 3) or polyhedral (facies 2). Contacts between these facies and the polymictic volcanic conglomerate are gradational.

saw-fit texture in facies 1 indicates that fragmentation occurred in situ. The occurrence of polyhedral sparsely porphyritic basalt clasts together with amoeboid clasts of the same composition in facies 3 confirms the largely in situ nature of the association - the amoeboid clasts have complete chilled margins and show no signs of abrasion resulting from particulate transport. Contacts among the three polymictic breccia facies and the overlying volcanic conglomerate are gradational, and some sparsely porphyritic basalt clasts include rounded porphyritic pebbles identical to those in the conglomerate. These relationships indicate that the polymictic breccia facies are a variety of peperite generated by intrusion of sparsely porphyritic basalt into coarse, unconsolidated volcanic gravel. Thus, facies 1 is the intensely fractured intrusion and facies 2 and 3 mark the transition into the coarse, volcaniclastic host succession. The angular, polyhedral and amoeboid sparsely porphyritic basalt clasts are in fact the igneous component of the peperite.

Domains dominated by the angular, polyhedral sparsely porphyritic basalt clasts (mainly facies 2) can be interpreted as blocky peperite (cf. BusbySpera and White, 1987). Some of the larger amoeboid clasts in facies 3 may be interconnected in three dimensions and resemble intrusive lobes or apophyses (cf. Busby-Spera and White, 1987; Boulter, 1993; Hanson and Hargrove, 1999). Domains dominated by the amoeboid, sparsely porphyritic basalt clasts (mainly facies 3 ) can be interpreted as fluidal peperite (cf. Busby-Spera and White, 1987).

The intervals dominated by the polymictic volcanic breccia facies association are broadly parallel to bedding, implying that the basaltic intrusions are most likely sills. No texturally similar extrusive basalt occurs at or above this level of the local stratigraphy so the sills are unlikely to originate from invasive lava(s). There are no firm constraints on the depth of emplacement of the basaltic sills; a relatively shallow depth $(<$ several tens of metres?) is likely, given the evidence that the host gravel was unconsolidated or poorly consolidated. 


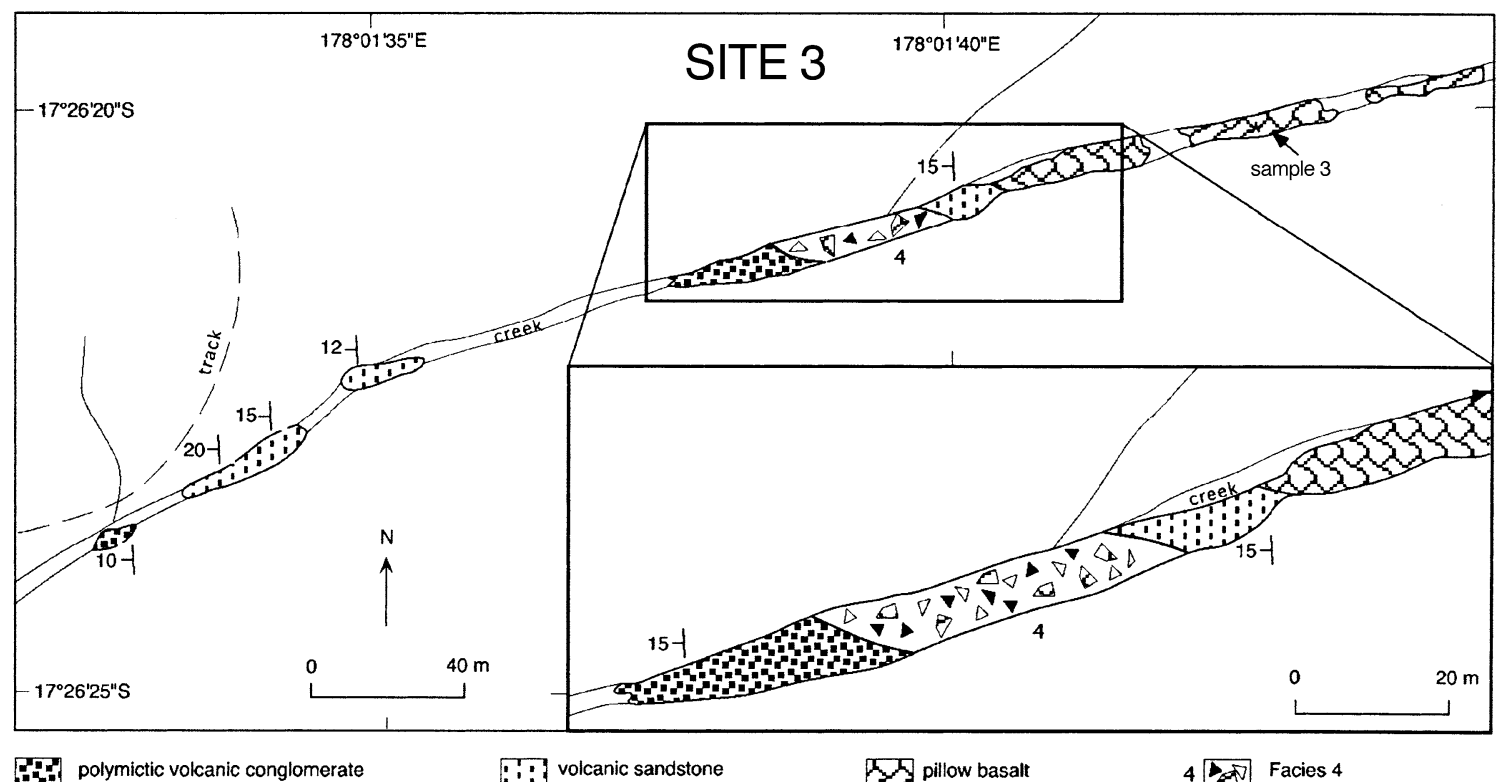

Fig. 5. Map of the volcanic facies along a major tributary of Naidadara Creek at site 3. The outcrop shown in detail comprises the pillow-fragment breccia (facies 4) with a gradational upper contact into polymictic volcanic conglomerate. A thick interval of pillow basalt is located near the base of the pillow-fragment breccia.

\section{Polymictic volcanic breccia with highly porphyritic basalt clasts (facies 4)}

Facies 4, unlike the other polymictic volcanic breccia facies, is stratified, interbedded with volcanic sandstone and polymictic volcanic conglomerate and contains minor sedimentary structures including crudely graded beds and diffuse crossstratification. This facies contains at least $40 \%$, large (up to $80 \mathrm{~cm}$ ), angular, blocky to irregularly shaped clasts of highly pyroxene-phyric, highly vesicular basalt. The large basaltic clasts are pillow fragments in which flow-aligned vesicle layers and glassy margins are truncated at subplanar clast margins (Fig. 11). This facies forms part of the interbedded sedimentary package overlying the pillow-basalt facies and is up to $8 \mathrm{~m}$ thick (Figs. 5 and 6).

In addition to pillow fragments, facies 4 consists of variable proportions of moderately wellsorted, clinopyroxene-rich, medium volcanic sandstone and abundant (at least 50\%) wellrounded, non-vesicular and highly vesicular, clinopyroxene-phyric basalt pebbles and cobbles (including sparse red and yellow oxidised clasts). An- gular to subangular fragments are also present (up to $30 \%$ ).

\subsection{Facies relationships and interpretation}

Facies 4 is superficially similar to facies 2 and 3 in containing a conspicuous population of angular, blocky and irregular, partly fluidal basalt clasts. However, in this case there is no positive evidence for intrusion and dynamic mingling of basalt with gravel. Rather, the presence of sedimentary structures including graded bedding and diffuse cross-bedding, the truncation of internal vesicle layering and glassy margins at clast boundaries, and the absence of any jigsaw-fit texture among the coarsely porphyritic basalt clasts in facies 4 , indicate that the clast assemblage underwent significant lateral transport and that this facies was deposited on the sea floor from a particulate current. The pillow fragments in this facies are texturally and mineralogically similar to the nearby or subjacent pillow basalt and may have been locally collected and redeposited by mass flows that also transported crystal-rich sand and coarsely porphyritic basalt pebbles and cobbles. 

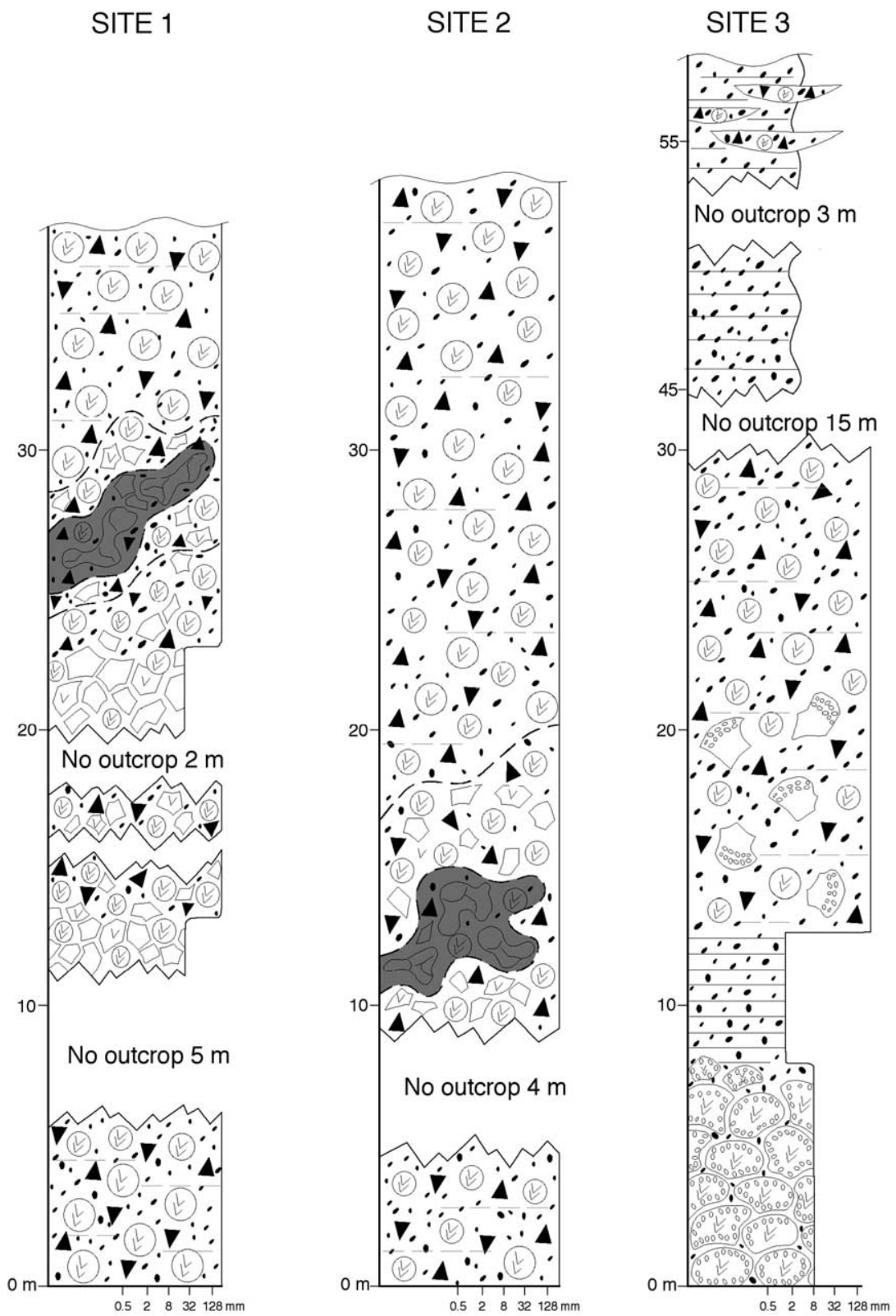

Fig. 6. Graphic logs summarising the distribution and thicknesses of the volcanic facies mapped at sites 1, 2 and 3 (Figs. 3,4 and 5, respectively) at Yaqara.

\section{Controls on igneous clast shapes in peperite: fluidal versus blocky}

At Yaqara, the sparsely porphyritic basalt sills have generated both blocky and fluidal peperite in poorly sorted polymictic volcanic conglomerate. In this case, factors other than the host sediment properties were apparently important in controlling the shapes of the igneous clasts (cf. BusbySpera and White, 1987). The igneous clast shapes 

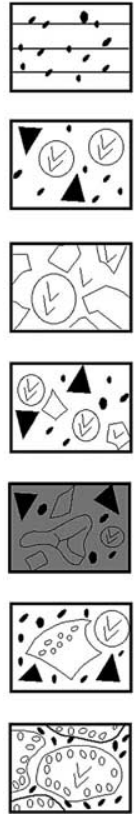

Volcanicsandstone

Polymictic volcanic conglomerate

Facies 1: intensely fractured basalt

containing volcanic pebbles and cobbles

Facies 2: blocky peperite in coarse

volcanic breccia host

Facies 3: fluidal peperite in coarse

volcanic breccia host

Facies 4: pillow fragment breccia

Pillow lava

Fig. 6 (Continued).

may instead reflect variations in the fragmentation processes ultimately controlled by the magma rheology. In particular, polyhedral clasts reflect a brittle response of the magma to stress, whereas the fluidal clasts imply dismembering of the magma in a ductile fashion. In circumstances involving a single magma composition, this contrast in behaviour is most likely to relate to magma viscosity which in turn, is highly sensitive to temperature (Shaw, 1969). An additional influence will be the strain rate. Blocky clasts are likely to reflect high strain rates, arising for example from marked gradients in magma supply, rapid cooling contraction or steam explosions.

\subsection{Fluidal peperite}

The presence of fluidal igneous clasts in peperite implies ductile fragmentation of relatively lowviscosity and hence high-temperature magma. In interactions with wet sediment, preservation of high temperatures requires insulation of the magma from direct contact with pore water. By analogy with the mechanism of pillow formation and the Leidenfrost effect (Mills, 1984), insulation depends on the formation of stable vapour films at the magma-host sediment interface (Kokelaar, 1982). Such vapour films can be generated and maintained providing a certain critical temperature (the Nukiyama temperature; Mills, 1984) is exceeded and there is a sufficient supply of pore fluid. In cases involving intrusions into wet sediment, these conditions will be met most readily during initial stages of interaction at the leading edges of advancing intrusions. With time, the magma will cool to the point where nucleation boiling rather than film boiling occurs (Mills, 1984) and the magma will no longer be insulated.

The amoeboid and fluidally shaped, sparsely porphyritic basalt clasts in the peperite at sites 1 and 2 (polymictic volcanic breccia facies 3 ) can be interpreted to reflect the initiation of film boiling along the contact surfaces of hot magma propagating through wet polymictic gravel. At this stage, insulating vapour films would have prevented direct magma-water/wet sediment contact and promoted ductile behaviour during dismembering of the advancing intrusion into magma 


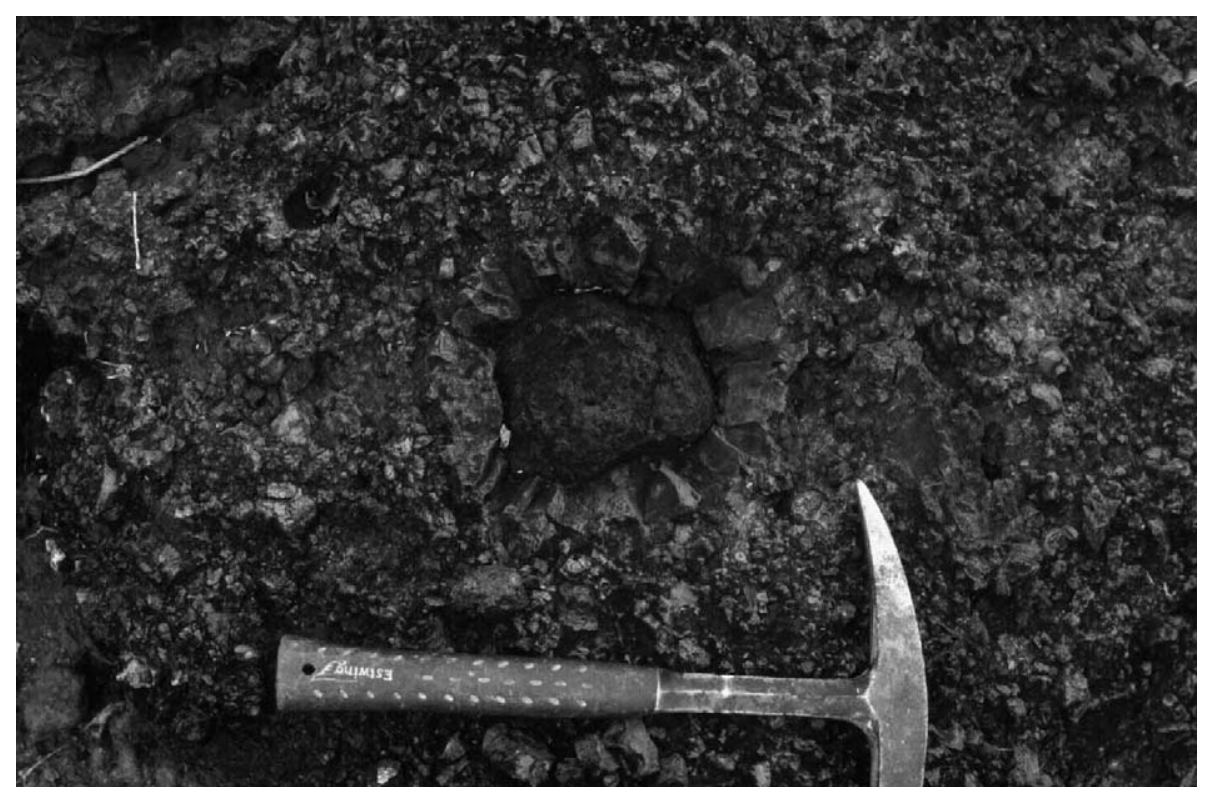

Fig. 7. A well-rounded, highly clinopyroxene-phyric basalt clast enclosed by the sparsely porphyritic basalt of facies 1 at site 1 . Radial fractures are present in the sparsely porphyritic basalt enclosing the rounded clast. Hammer is $32 \mathrm{~cm}$ long.

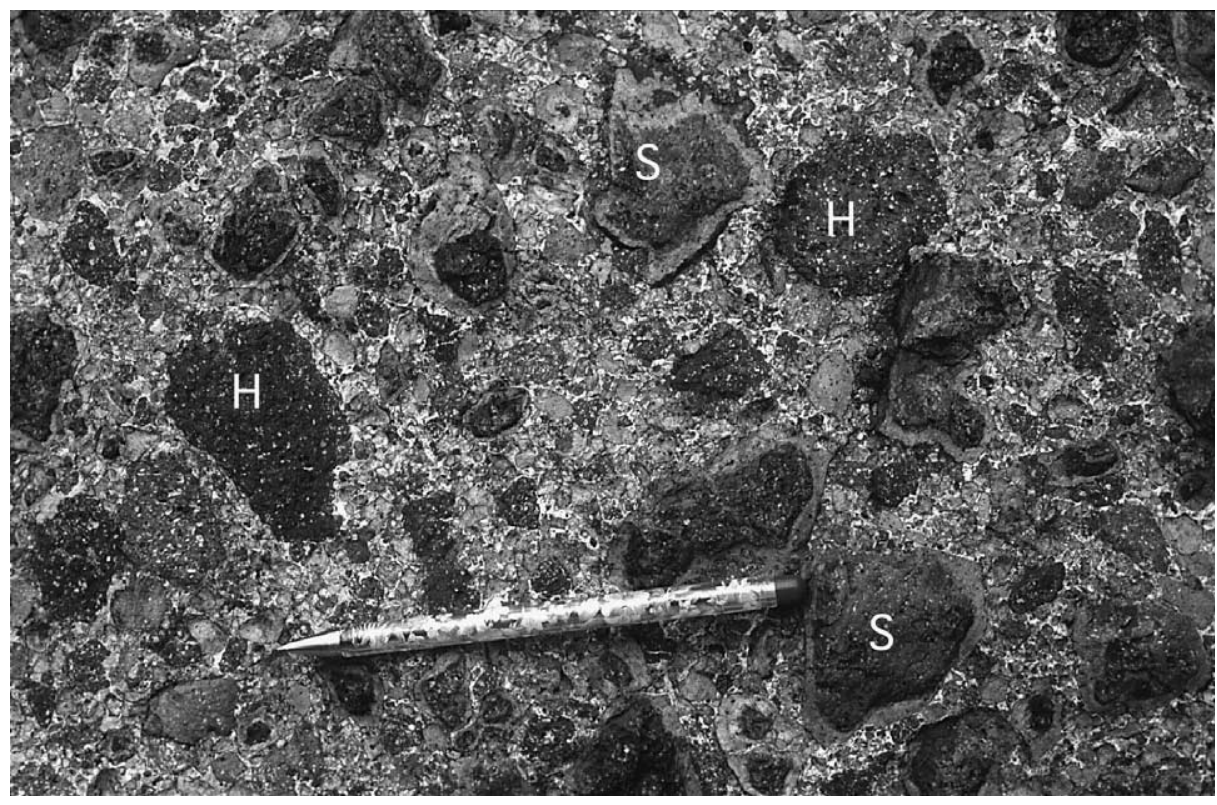

Fig. 8. Facies 2 polymictic volcanic breccia at site 2, dominated by angular, polyhedral, sparsely porphyritic basalt clasts (S) but also containing scattered highly porphyritic basalt clasts $(\mathrm{H})$. The sparsely porphyritic clasts have well-defined, complete quenched margins. Elsewhere, jigsaw-fit texture is present in this facies. The highly porphyritic clasts are similar in shape and texture to clasts in the polymictic volcanic conglomerate facies (Fig. 2). Facies 2 is thus interpreted to be blocky peperite. Pen is $14.5 \mathrm{~cm}$ long. 


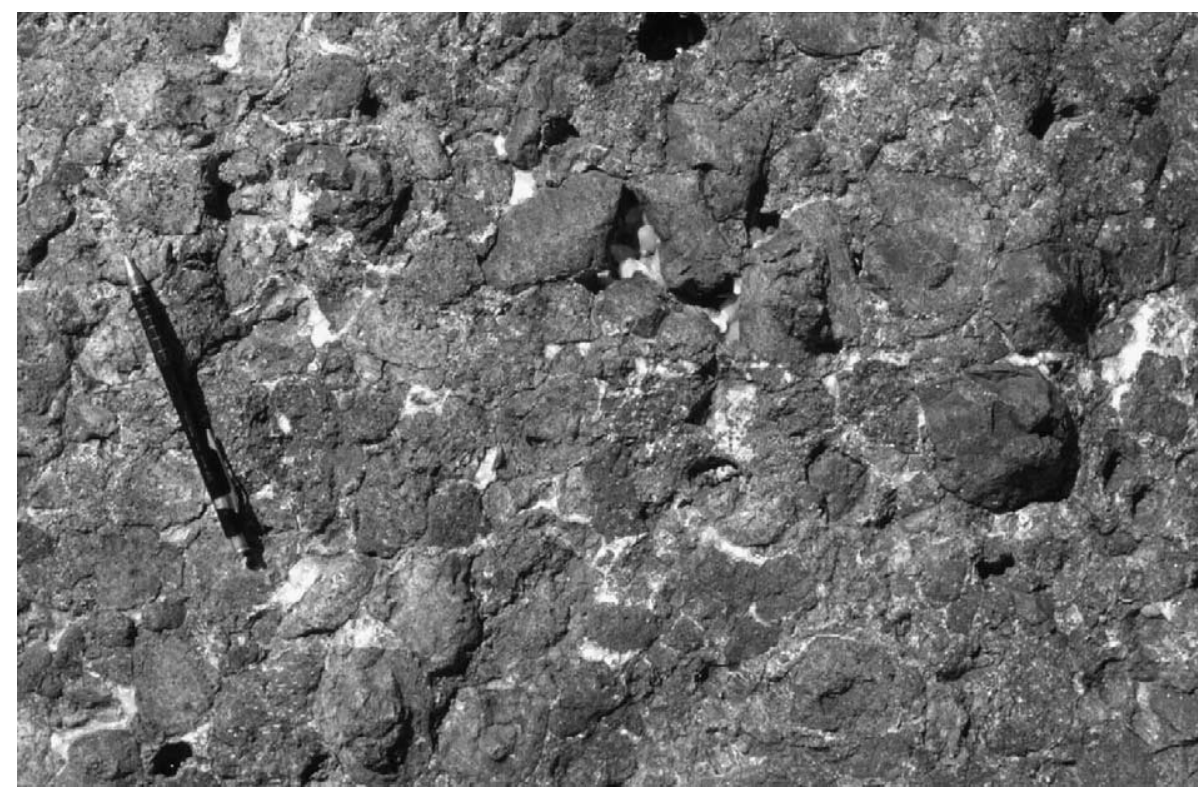

Fig. 9. Quartz-filled cavities in facies 2 of the polymictic volcanic breccia with sparsely porphyritic basalt clasts (blocky peperite) at site 2 . Pencil is $14.5 \mathrm{~cm}$ long.

lobes and apophyses. Any marked fluctuations in magma supply might be expected to result in momentary elevation of the strain rate and hence, brittle rather than ductile fragmentation. It thus appears that magma supply during early stages of intrusion was sufficiently steady to allow a plastic and ductile response to stress.

\subsection{Blocky peperite}

Where intrusions invade wet sediment, fragmentation processes capable of generating angular, polyhedral igneous clasts are quenching, dynamic stressing and steam-driven explosions. In the case of quenching, magma fragments in a brittle fashion in response to thermal stresses induced by cooling contraction (Kokelaar, 1986). Quench fragmentation largely operates in situ and produces blocky clasts with chilled margins in aggregates that show jigsaw-fit and clast-rotated textures. Dynamic stressing involves the disintegration and brittle fracture of more viscous, chilled parts of lavas and intrusions in response to injection of additional magma (Kokelaar, 1986). This process is likely to accompany and contribute to quench fragmentation. In the case of steam-driven explosions, magma that engulfs pore fluid-sediment mixtures is fragmented and clasts are dispersed by rapidly expanding, superheated pore fluid ('bulk interaction steam explosion', Kokelaar, 1986; 'clast blocking', BusbySpera and White, 1987). This process can also produce blocky clasts but they are dispersed in the host sediment and jigsaw-fit texture does not occur. An obvious constraint on this process is the confining pressure imposed by a combination of the overlying wet sediment and water column.

The presence of polyhedral igneous clasts with glassy margins and domains of jigsaw-fit texture in the blocky peperite involving sparsely porphyritic basalt (facies 2) suggests that magma fragmentation occurred mainly in response to quenching. Domains lacking jigsaw-fit and igneous clasts isolated in the coarse gravel host probably reflect a contribution from dynamic stressing. Quenching requires direct magma-wet sediment contact and the brittle behaviour of the magma reflects relatively high viscosity. Both these circumstances are likely to accompany cooling of the intrusion because lower temperatures preclude film boiling 


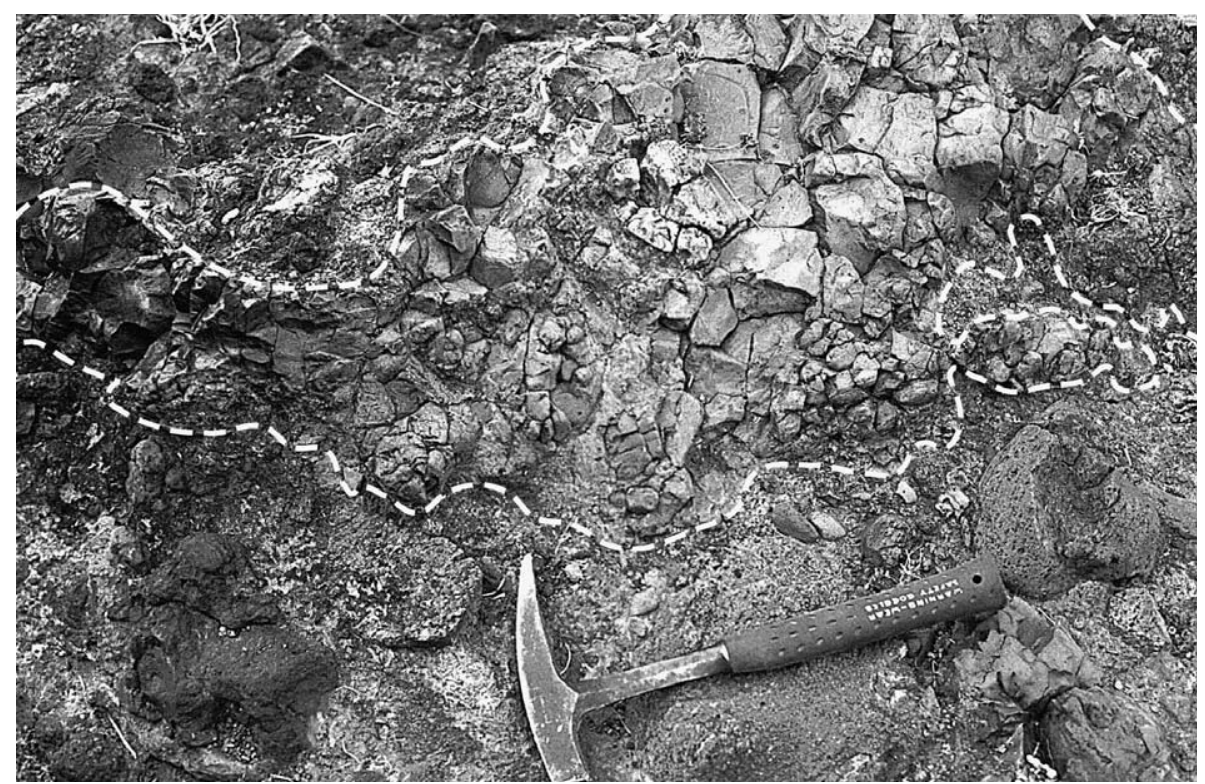

Fig. 10. Polyhedral joints in the amoeboid, sparsely porphyritic basalt clasts of facies 3 at site 1 . The amoeboid clasts have complete glassy (chilled) margins. This facies is interpreted to be fluidal peperite. Hammer is $32 \mathrm{~cm}$ long.

and also result in increases in magma viscosity. The jigsaw-fit fracture network in the sparsely porphyritic basalt of facies 1 reflects the propagation of the cooling and quench fragmentation front into the intrusion, generating in situ intrusive hyaloclastite.

Kokelaar (1986) proposed that early-formed peperite may be progressively disrupted during forceful emplacement of new magma pulses, generating igneous clasts that are isolated in the host sediment and that do not show jigsaw-fit textures. This process could account for dispersal of some polyhedral, sparsely porphyritic basalt clasts in the host sediment in facies 2 and 3. Dispersal of igneous clasts in blocky peperite has also been attributed to minor steam explosions (Kokelaar, 1986; Busby-Spera and White, 1987; Brooks, 1995; Hanson and Hargrove, 1999). The geological evidence of this process occurring during magma-wet sediment interaction is rather elusive; one positive indicator could be the presence of particles derived from the sediment within the igneous clasts, reflecting engulfment of wet sediment by hot magma. Single pebbles and cobbles of coarsely porphyritic basalt occur within the sparsely porphyritic basalt clasts of facies 1 and could be the record of engulfment that led to steam explosions. However, passive engulfment would produce the same relationship. Steam explosions may have contributed to the formation of the blocky peperite but there is no positive evidence that they did.

\subsection{Temporal relationships between blocky and fluidal peperite}

In facies 3, both blocky and fluidal igneous clasts are present and interpreted to represent sequential generation of peperite at the one locality, rather than the simultaneous co-existence of different fragmentation processes and magma properties. The timing of formation of the blocky and fluidal peperite facies involving sparsely porphyritic basalt at Yaqara is well constrained. The common jigsaw-fit fracture network in the sparsely porphyritic basalt of facies 1 is undisturbed, and this facies must represent the final pulse of magma. Facies 2 also involves large domains in which the igneous clasts show jigsaw-fit texture and have not been significantly disturbed. In addition, for- 


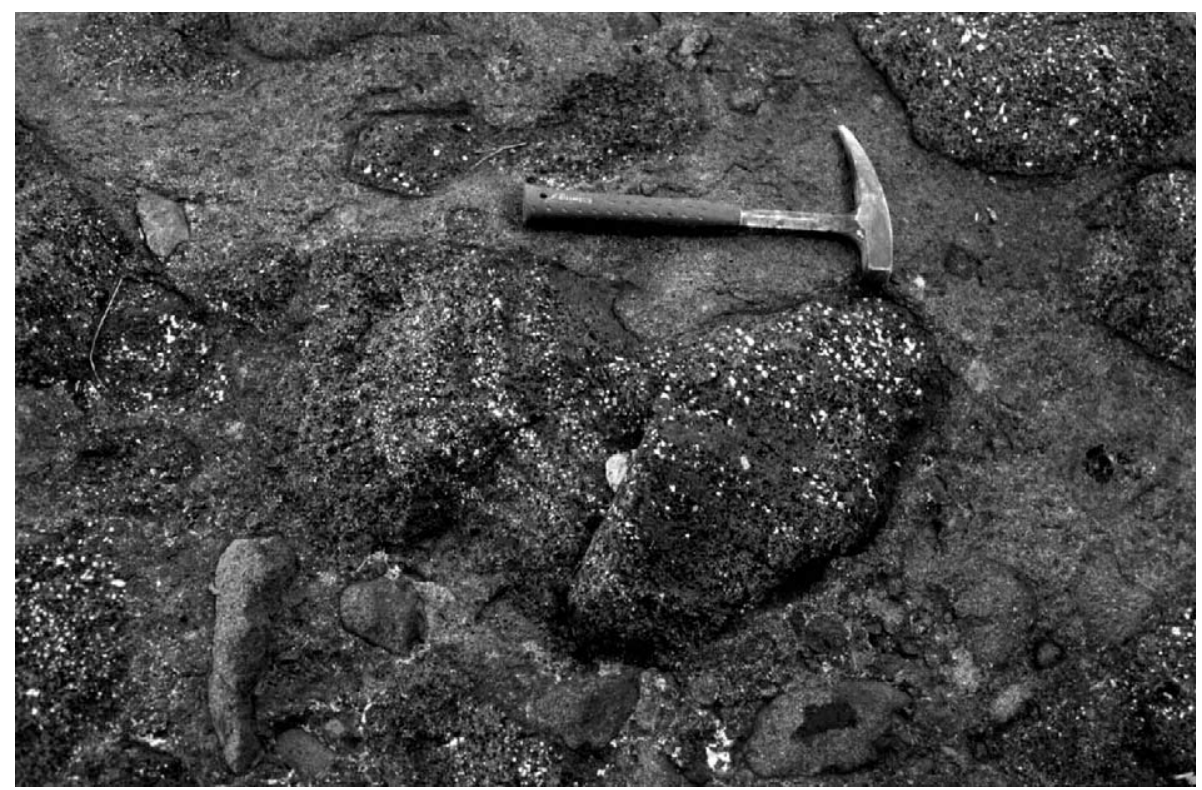

Fig. 11. Facies 4 polymictic volcanic breccia (site 3) containing large clasts of highly pyroxene-phyric and highly vesicular basalt. The flow-aligned vesicle layers and glassy margins are truncated at clast margins. This facies is interpreted to be pillow-fragment breccia. Hammer is $32 \mathrm{~cm}$ long.

mation of the blocky peperite of facies 2 probably involved a cooler magma temperature than that for formation of the fluidal peperite. Thus, the blocky peperite (mainly facies 2) was probably formed later than the fluidal peperite (facies 3). The dispersal of blocky clasts among fluidal clasts in facies 3 also implies that fluidal peperite formed first.

Advancing intrusions may propagate as lobes and digits but only those lobes that maintain a high temperature go on to produce fluidal peperite during mixing (e.g. facies 3). Other lobes propagating at lower temperature or during periods of unsteady magma supply disintegrate to form blocky peperite.

\section{Role of fluidisation and host sediment properties}

Intrusions of hot magma into wet sediment can generate a supply of water vapour sufficient to sustain fluidisation, providing the confining pressure does not exceed the critical pressure of water (Kokelaar, 1982). Fluidisation of the wet sedi- ment could be very important in partly solving the 'space problem' that accompanies intrusion. Entrainment of sediment in narrow zones of escaping pore fluid along magma contacts can effectively disrupt and displace the sediment. Evidence for this process is best known from peperite involving fine-grained host sediment in which bedding and other sedimentary structures have been destroyed along intrusive contacts (e.g. Kokelaar, 1982; Brooks, 1995).

Destruction of bedding cannot be recognised in the Yaqara peperite because the host sediment is coarse-grained and very thickly bedded. However, small (up to $4 \mathrm{~cm}$ ) cavities that occur in the host sediment could indicate the former presence of a gas phase. These cavities are restricted to the blocky peperite (facies 2) and only found in the domains dominated by the polyhedral, sparsely porphyritic clasts (Fig. 9). The gas phase could have been steam generated from heating of the pore fluids by the intruding basalt and raises the possibility that at least partial fluidisation may have operated. In that case, only the fine-grained fraction of the particle population could have 


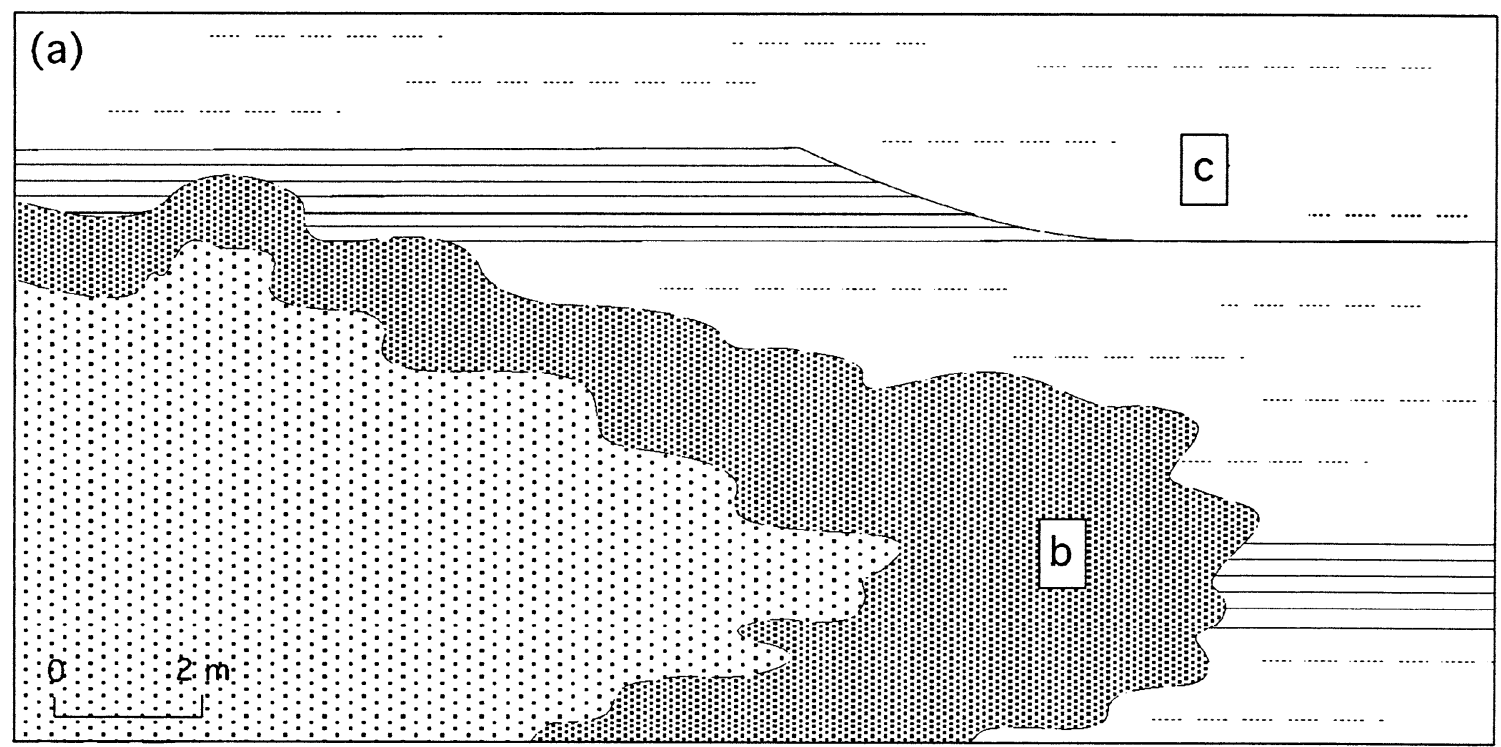

$\therefore:$ Facies 1

(b)

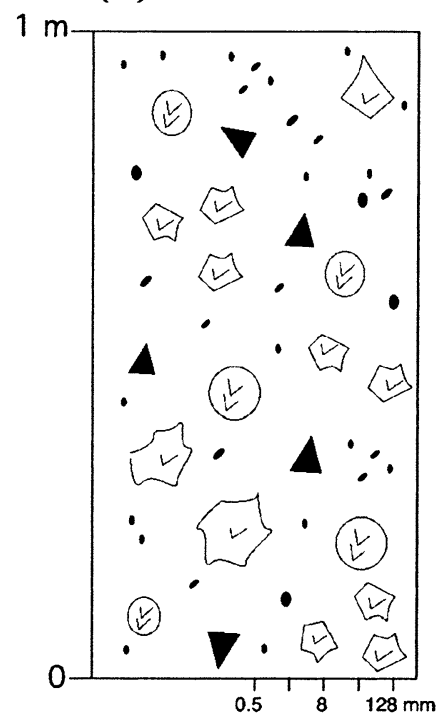

(c)

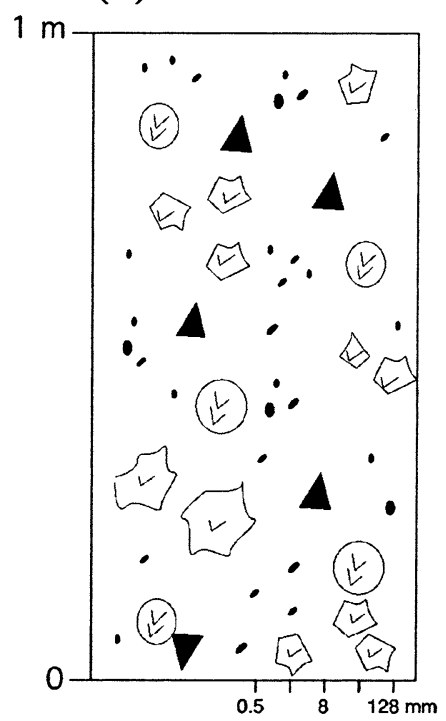

Fig. 12. (a) Cartoon showing two exposures (insets (b) and (c)) of polymictic volcanic breccia which appear to be identical although one is in peperite and the other is in resedimented gravel. Graphic logs (b) and (c) illustrate the similarities of the isolated exposures. Correct discrimination of the blocky peperite (facies 2) at locality (b) from the resedimented polymictic volcanic gravels at locality (c) requires sufficient exposure to distinguish internal lithofacies characteristics, context and contact relationships with adjacent facies. 
been fluidised and separated from the larger pebbles and cobbles, some of which were evidently engulfed by the advancing magma.

Busby-Spera and White (1987) concluded that the physical properties of the host sediment influenced formation of fluidal versus blocky peperite in the Alisitos Group, Mexico. Fluidal peperite was restricted to areas where magma intruded fine-grained sediment in which vapour films could be maintained at the magma-sediment interface. Blocky peperite, however, developed in poorly sorted, coarse-grained sediments in which insulating vapour films could not be maintained. Although fluidal and blocky peperite both occur in coarse-grained, poorly sorted host sediment at Yaqara, the host sediment grain size and permeability may still have exerted an important influence. In particular, because the supply of fine sediment was limited, any vapour-film-driven fluidisation can only have been transient and would eventually break down, allowing direct magmawet sediment contact. Such a sequence would generate fluidal peperite first, followed by blocky peperite, consistent with the order of formation inferred above.

\section{Identification of peperite involving coarse-grained host sediment}

In cases where magma intrudes and mixes with unconsolidated, coarse, polymictic volcanic gravel, igneous clasts derived from the intruding magma may be very difficult to distinguish from volcanic clasts in the host sediment (Fig. 12). Peperite of this type can be easily overlooked. On the other hand, volcanic breccias or conglomerates with populations of distinctive fluidal and blocky igneous clasts are not necessarily peperite. Correct identification of peperite in coarse volcaniclastic host successions depends on textural and lithofacies evidence indicating that (a) the igneous component was molten and the host succession was unconsolidated at the time of interaction, and (b) mixing occurred subsurface during intrusion. The key criteria for recognising peperite involving sparsely porphyritic basalt and coarse, polymictic volcaniclastic host sediment in the ex- amples from Yaqara include the presence of the following:

(1) Gradational contacts between adjacent lithofacies. Contacts between polymictic volcanic conglomerate, fluidal peperite (facies 3), blocky peperite (facies 2) and the margin of the intrusion (facies 1) are gradational. There are no discontinuities within the stratigraphic interval spanned by these facies that might indicate the presence of bedding planes.

(2) Fluidally shaped clasts. The fluidal and irregular, amoeboid basalt clasts in facies 3 have complete, glassy (chilled) margins that indicate that the basalt must have been molten and ductile at least momentarily during mixing.

(3) Jigsaw-fit textures. The presence of jigsaw-fit texture in groups of sparsely porphyritic basalt clasts in facies 2 and throughout the sparsely porphyritic basalt of facies 1 indicates that fragmentation occurred in situ, after incorporation in the host gravel.

(4) Host sediment clasts within basalt. Some sparsely porphyritic basalt clasts in facies 1 and facies 2 include single isolated pebbles and cobbles of highly porphyritic basalt derived from the host sediment. This implies that the host sediment was unconsolidated and easily disaggregated by the advancing intrusion.

(5) Cavities in the host sediment. Small quartzfilled cavities locally present within facies 2 indicate that small-scale particle rearrangement and intergranular movement of the entrapped fluid phase took place and suggest that the host sediment was unconsolidated.

Careful application of these criteria at Yaqara enabled discrimination of genuine peperite among texturally diverse, coarse polymictic volcaniclastic facies that include examples of 'apparent' peperite. For example, facies 4 polymictic breccia resembles peperite involving coarse volcaniclastic host sediment and highly porphyritic basalt. This facies includes a conspicuous population of texturally identical, blocky to irregularly shaped, highly porphyritic basalt clasts. However, the peperite interpretation can be discounted because the facies is stratified, the highly porphyritic basalt clasts have incomplete glassy margins and jigsaw-fit texture is absent. 


\section{Conclusions}

Sills of sparsely porphyritic basalt have generated peperite in coarse, poorly sorted, polymictic, volcanic gravel of the $\mathrm{Ba}$ Volcanic Group at Yaqara. The peperite superficially resembles other polymictic volcanic breccias and conglomerates in the succession but is distinguished by the presence of groups of basalt clasts that show jigsaw-fit texture, fluidally shaped basalt clasts with complete glassy margins, gradational contacts into adjacent sedimentary facies and the absence of stratification.

Both polyhedral and fluidal basalt clasts occur in the peperite at the same location, and represent the superimposed products of sequential stages of magma-wet sediment interaction. The amoeboid shapes of the basalt clasts in the fluidal peperite indicate ductile, relatively low-viscosity behaviour of the magma and probably developed at an early stage while a vapour film insulated the magma from direct contact with the wet sediment. The angular, polyhedral shapes of the basalt clasts in the blocky peperite indicate brittle fragmentation that probably resulted from quenching of somewhat cooler, higher-viscosity magma at a later stage. The change from fluidal to blocky peperite formation might have also coincided with the breakdown of fluidisation when the limited supply of fine sediment in the host gravel was exhausted. Although there is no positive evidence for steam explosivity, the presence of steam could be recorded by small cavities that occur within the host sediment in the blocky peperite.

\section{Acknowledgements}

This research has been supported by a CODES SRC Research Grant. Bhaskar Rao from the Mineral Resources Department of Fiji is thanked for assistance and comments in the field, in particular arranging access onto the Yaqara Pastoral Station. Thin sections were prepared by Simon Stephens and XRF analyses performed by Phil Robinson, both from the University of Tasmania. Careful reviews by Michael Ort, Elwood Brooks and Ian Skilling are gratefully acknowledged.

\section{References}

Boulter, C.A., 1993. High-level peperitic sills at Rio Tinto, Spain: implications for stratigraphy and mineralisation. Trans. Inst. Min. Metall. (Sect. B: Appl. Earth Sci.) 102, B30-B38.

Brooks, E.R., 1995. Paleozoic fluidization, folding, and peperite formation, northern Sierra Nevada, California. Can. J. Earth Sci. 32, 314-324.

Brooks, E.R., Wood, M.W., Garbutt, P.L., 1982. Origin and metamorphism of peperite and associated rocks in the Devonian Elwell Formation, northern Sierra Nevada, California. Geol. Soc. Am. Bull. 93, 1208-1231.

Busby-Spera, C.J., White, J.D.L., 1987. Variation in peperite textures associated with differing host-sediment properties. Bull. Volcanol. 49, 765-775.

Colley, H., Flint, D.J., 1995. Metallic mineral deposits of Fiji. Mem. 4, Miner. Resour. Dept. Fiji.

Colley, H., Greenbaum, D., 1980. The mineral deposits and metallogenesis of the Fiji Platform. Econ. Geol. 75, 807-829.

Colley, H., Hindle, W.H. (Eds.), 1984. Volcano-tectonic evolution of Fiji and adjoining marginal basins. Marginal basin geology; volcanic and associated sedimentary and tectonic processes in modern and ancient marginal basins Geol. Soc. London, Spec. Publ. 16, 151-162.

Dickinson, W.R., 1968. Sedimentation of volcaniclastic strata of the Pliocene Koroimavua Group in northwest Viti Levu, Fiji. Am. J. Sci. 266, 440-453.

Gill, J.B., 1987. Geodynamic and geochemical evolution of the Fiji region. Proc. Pacific Rim Congr. Aust. Inst. Min. Metall., pp. 125-128.

Goto, Y., McPhie, J., 1996. A Miocene basanite peperitic dyke at Stanley, northwestern Tasmania, Australia. J. Volcanol. Geotherm. Res. 74, 11-120.

Hanson, R.E., 1991. Quenching and hydroclastic disruption of andesitic to rhyolitic intrusions in a submarine island-arc sequence, northern Sierra Nevada, California. Geol. Soc. Am. Bull. 103, 804-816.

Hanson, R.E., Hargrove, U.S., 1999. Processes of magma/wet sediment interaction in a large-scale Jurassic andesitic peperite complex, northern Sierra Nevada, California. Bull. Volcanol. 60, 610-626.

Hanson, R.E., Wilson, T.J., 1991. Submarine rhyolitic volcanism in a Jurassic proto-marginal basin; Southern Andes, Chile and Argentina. In: Harmon, R.S., Rapela, C.W. (Eds.), Andean Magmatism and its Tectonic Setting. Geological Society of America, Boulder, CO, pp. 13-27.

Hanson, R.E., Wilson, T.J., 1993. Large-scale rhyolite peperites (Jurassic, Southern Chile). J. Volcanol. Geotherm. Res. 54, 247-264.

Kokelaar, B.P., 1982. Fluidization of wet sediments during the emplacement and cooling of various igneous bodies. J. Geol. Soc. London 139, 21-33.

Kokelaar, B.P., 1986. Magma-water interactions in subaqueous and emergent basaltic volcanism. Bull. Volcanol. 48, 275-289.

Le Maitre, R.W., Bateman, P., Dudek, A., Keller, J., Lameyre Le Bas, M.J., Sabine, P.A., Schmid, R., Sorensen, H., 
Streckeisen, A., Woolley, A.R., Zanettin, B., 1989. A Classification of Igneous Rocks and Glossary of Terms. Blackwell, Oxford.

McPhie, J., 1995. A Pliocene shoaling basaltic seamount: Ba Volcanic Group at Rakiraki, Fiji. J. Volcanol. Geotherm. Res. 64, 193-210.

Mills, A.A., 1984. Pillow lavas and the Leidenfrost effect. J. Geol. Soc. London 141, 183-186.

Mueller, W., Chown, E.H., Potvin, R., 1994. Substorm wave base felsic hydroclastic deposits in the Archean Lac des Vents volcanic complex, Abitibi Belt, Canada. J. Volcanol. Geotherm. Res. 60, 273-300.

Rawlings, D.J., 1993. Mafic peperite from the Gold Creek Volcanics in the Middle Proterozoic Mc Arthur Basin, Northern Territory. Aust. J. Earth Sci. 40, 109-113.

Rickwood, P.C., 1989. Boundary lines within petrologic diagrams which use oxides of major and minor elements. Lithos 22, 247-263.

Rodda, P., 1967. Outline of the geology of Viti Levu. N.Z. J. Geol. Geophys. 10, 1260-1273.

Rodda, P., 1976. Geology of northern and central Viti Levu. Bull. 3, Miner. Resour. Div. Fiji.
Rodda, P., Kroenke, L.W., 1984. Fiji: a fragmented arc. In: Kroenke, L.W. (Ed.), Cenozoic Tectonic Development of the Southwest Pacific. CCOP/SOPAC Tech. Bull, pp. 87109.

Seeley, J.B., Searle, E.J., 1970. Geology of the Rakiraki district, Viti Levu, Fiji. N.Z. J. Geol. Geophys. 13, 52-71.

Shaw, H.R., 1969. Rheology of basalt in the melting range. J. Petrol. 10, 510-535.

Whelan, P.M., Gill, J.B., Kollman, E., Duncan, R.A., Drake, R.E., 1985. Radiometric dating of magmatic stages in Fiji. In: Scholl, D.W., Vallier, T.L. (Eds.), Geology and Offshore Resources of Pacific Island Arcs-Tonga Region. Circum-Pacific Counc. Energ. Miner. Resour., Earth Sci. Ser., pp. 415440.

White, J.D.L., Busby-Spera, C.J., 1987. Deep marine arc apron deposits and syndepositional magmatism in the Alisitos Group at Punta Cono, Baja California, Mexico. Sedimentology 34, 911-927.

Yamagishi, H., 1991. Morphological and sedimentological characteristics of the Neogene submarine coherent lavas and hyaloclastites in southwest Hokkaido, Japan. Sediment. Geol. 74, 5-23. 